không có ý nghĩa thống kê với $p>0.05$. Trong nghiên cứu của chúng tôi số bệnh nhân có tiền sử tiêm phòng HPV chỉ co 8 người, đều có kết quả âm tính HPV.

4.4 Về phân bố genotype HPV trong nhóm nghiên cứu. Về phân bố tỷ lệ các type trong nhóm dương tính HPV chúng tôi nhận thấy, nhóm bệnh nhân có kết quả dương tính với 1 trong 12 type nguy cơ cao khác chiếm đa số là $60.92 \%$; trong khi số bệnh nhân chỉ dương tính với type 18 chỉ có 1 bệnh nhân. Trong khi đó sô bệnh nhân có kết quả dương tính với cả 2 type nguy cơ cao chiếm phần lớn hơn so với nhiềm đồng thời cả 3 type nguy cơ cao trở lên. Kết quả của chúng tôi giống với nghiên cứu của Vũ Văn Tâm và cộng sự [6]: số bệnh nhân nhiễm 1 trong 12 type là $66.7 \%$, chiếm đa số trong các bệnh nhân có kết quả dương tính.

\section{KẾT LUÂ̂N}

- Số người dưới 25 tuổi có kết quả nhiễm HPV dương tính là 45,8\%. Trong đó các bệnh nhân dương tính HPV dưới 35 tuổi cao hơn nhóm tuổi trên 35 tuổi.

- Không có sự khác biêt có ý nghĩa thống kê về giới và địa dư trong nhóm nghiên cứu.

- Số bệnh nhân nhiễm 1 trong 12 type nguy cơ cao khác type-16 và type 18 cao hơn, chiếm $60,92 \%$.

\section{TÀI LIÊU THAM KHẢO}

1. Manini, E.Montomoli, 2018, "Epidemiology and prevention of Human Papillomavirus", Ann Ig, 30, 28-32

2. Anna R. Giuliano et al, 2008, "Epidemiology of Human Papillomavirus Infection in Men, in Cancers other than Cervical and in Benign Conditions", HHS Public Access, 26, 17-28.

3. Renjie Wang et al, 2020, "Human papillomavirus vaccine against cervical cancer: Opportunity and challenge", Cancer Lett, 471, 88-102.

4. David Forman et al, 2012, "Global burden of human papillomavirus and related diseases", Vaccin, 30, 12-23.

5. Rong WaNG et al, 2015, "Nationwide prevalence of human papillomavirus infection and viral genotype distribution in 37 cities in China", BMC Infect Dis, 15, 257

6. Vũ Văn Tâm và cộng sự, "Nghiên cứu tỷ lệ nhiếm HPV ở bệnh nhân có tổn thương cổ tử cung tại Bệnh viện Phụ Sản hải Phòng bằng kỹ thuật Real-time PĆR và Reverse Dot Blot Hybridization" "

7. Lâm Đức Tâm, 2017, "Nghiên cứu tỷ lệ nhiễm Human Papillomavirus, môtt số yếu tố liên quan và kết quả điêu trị các tốn thương cố tử cung ở phụ nữ thành phố Cần Tho"

8. Trân Thi Thanh Tuyên, Pham Văn Hâu, 2020, "Tình trạng quan hệ tình dục trước hôn nhân và một số yếu tố liên quan của sinh viên một trường cao đẳng tại thành phố Hồ Chí Minh", Tạp chí Y hoc dư phòng, 30.

9. Đố Thị Hạnh Trang và công sự, 2015, "Thực trang quan hệ tình dục trước hôn nhân và một số yểu tố liên quan của sinh viên trường Đại học Nội vụ năm 2015"

\title{
RỐI LOẠN ĐIÊ̂N GIẢI, CANXI, MAGIE VÀ PHOSPHO Ở BỆNH NHÂN XO' GAN DO RƯợU
}

\section{TÓM TẮT}

Đặt vấn đề: Bệnh gan do rượu bao gồm nhiễm mõ do rượu, viêm gan do rượu và xơ gan do rượu, theo thứ tự tăng mức độ nghiểm trong. Có nhiều biến chứng của bệnh gan do rượu tiến triển, một trong số đó là rối loan chuyển hóa. Muc tiêu: Mô tả sự phổ biến và mối liên quan của rối loạn chất điện giải, chuyển hóa khoáng chất với một số yếu tố ở bệnh nhân xơ gan do rượu. Phương pháp: Nghiên cứu được thực hiên trên 66 bệnh nhân bị xơ gan do rượu (65 nam, 1 nữ;; tuổi trung bình 55,98 \pm 11,25). 6 bệnh

\footnotetext{
${ }^{1}$ Trường Đại học Y Dược Thái Nguyên

²Bênh viện trung ương quân đội 108

Chịu trách nhiệm chính: Đồng Đức Hoàng

Email: Drhoang85@gmail.com

Ngày nhận bài: 13.11.2020

Ngày phản biên khoa họ: 29.12.2020

Ngày duyệt bài: 6.01.2021
}

Đồng Đức Hoàng ${ }^{1}$, Dương Thị Tuyết ${ }^{2}$

nhân thuộc Child $A$, trong khi 30 Child $B$ và 30 Child $C$. Mẫu máu bệnh nhân được thu thập, xét nghiệm và ghi lại kết quả. Kết quả: Hạ natri máu được tìm thấy ở 62,1\% bệnh nhân (tối thiểu, tối đa: 118-141 mmol/L). Tỷ lệ hạ kali máu: 30,3\%, tăng kali máu: 9,1\% (tối thiểu, tối đa: 1,8-5,8 mmol/L). Hạ clo máu là 39,4\%, tăng clo máu: 16,7\%, tối thiểu, tối đa (75-114). Hạ canxi máu rất phổ biến $(75,8 \%)$, tối thiểu, tối đa $(1,34-2,54)$. Có tỷ lệ hạ magie máu cao $(68,2 \%)$, tối thiểu, tối đa $(0,33-1,09)$. Ha phospho máu là $22,7 \%$, tăng phospho máu là $4,5 \%$, tối thiểu, tối đa $(0,40-$ $2,01)$. Trong số các chất điện giải, khoáng chất, $\mathrm{K}^{+}$ (Child A: 4,4 $\pm 0,8$, Child B: 4,1 $\pm 0,8$, Child C: $3,4 \pm$ 0,$7 ; p=0,002$ ) và $\mathrm{Ca}^{++} \mathrm{TP}$ (Child $A: 2,2 \pm 0,1$, Child B: $2,1 \pm 0,2$, Child $C: 1,9 \pm 0,1 ; p=0,01)$ giảm theo mức độ mất bù của xơ gan, các chất khác thay đổi không có ý nghĩa thống kê. Kali huyết thanh trung bình khi không có suy thận là $3,6 \pm 0,7$, tăng khi có suy thận $4.2 \pm 1.1, p<0,05$, các chất khác thay đổi không có ý nghĩa thống kê. Giá trị trung bình của canxi huyết thanh là 2,13 $\pm 0,20$, giảm xuống 2,01 \pm 
0,18 khi có cổ trướng, $\mathrm{p}<0,05$, các chất khác thay đổi mà không có ý nghĩa thống kê. Kết luận: Tỷ lệ giảm chất điện giải và khoáng chất là phổ biến nhất theo thứ tự $\mathrm{Ca}, \mathrm{Mg}, \mathrm{Na}, \mathrm{Cl}, \mathrm{K}$, Pho. Hạ kali máu, hạ canxi máu có mối quan hệ với mức độ xơ gan, tăng kali khi suy thận, giảm canxi khi cổ trướng.

Từ khóa: Bệnh gan do rượu, rối loạn điện giải, rối loạn chuyển hóa khoáng chất.

\section{SUMMARY \\ DISORDERS OF ELECTROLYTES, CALCIUM, MAGNESIUM AND PHOSPHORUS IN \\ ALCOHOLIC CIRRHOSIS PATIENTS}

Background: Alcoholic liver disease includes alcoholic steatosis, alcoholic hepatitis, and alcoholic cirrhosis, in order of increasing severity. There are many complications of advanced alcoholic liver disease, one of those is disorders of metabolism. Aim: to describe the prevalence and association of electrolytes, mineral metabolism disorder with some factors in alcoholic cirrhosis patients. Methods: The study was performed on 66 patients with alcoholic cirrhosis (65 male, 1 female; mean aqed $55.98 \pm$ 11.25 years). 6 patients belonged to Child $A$, while 30 were in Child B and 30 in Child C. Patient's blood samples were collected, tested and results recorded. Results: Hyponatremia was found in $62.1 \%$ of patients (min, max: 118-141 $\mathrm{mmol} / \mathrm{L}$ ). Rate of hypokalemia: $30.3 \%$, hyperkalemia: $9.1 \%$ (min, $\max$ 1.8-5.8 mmol/L). Hypochloremia was 39.4\%, hyperchloremia: $16.7 \%$, $\min$, $\max (75-114)$. Hypocalcemia was highly prevalent $(75.8 \%)$, min, max (1.34-2.54). There was a high incidence of hypomaqnesemia $(68.2 \%)$, min, $\max (0.33-1.09)$. Hypophosphatemia was $22.7 \%$, hyperphosphatemia was $4.5 \%$, min, $\max (0.40-2.01)$. Amonq electrolytes, mineral, $\mathrm{K}^{+}$(Child A: $4.4 \pm 0.8$, Child B: $4.1 \pm 0.8$, Child C: $3.4 \pm 0.7 ; \mathrm{p}=0.002$ ) and total $\mathrm{Ca}^{++}$(Child $\mathrm{A}$ : $2.2 \pm 0.1$, Child B: $2.1 \pm 0.2$, Child C: $1.9 \pm 0.1 ; p=$ 0.01 ) decreased follow with the decompensated deqree of cirrhosis, other substances change without statistical significance. Serum potassium mean in no kidney failure was $3.6 \pm 0.7$, increased when kidney failure $4.2 \pm 1.1, \mathrm{p}<0.05$, other substances change without statistical significance. Serum calcium mean was $2.13 \pm 0.20$, decreased to $2.01 \pm 0.18$ when ascites, $\mathrm{p}<0.05$, other substances change without statistical significance. Conclusion: Prevalence of decreasing electrolytes and minerals is most common in the order of $\mathrm{Ca}, \mathrm{Mg}, \mathrm{Na}, \mathrm{Cl}, \mathrm{K}$, Pho. Hypokalemia, hypocalcemia is relationship with cirrhosis degree, potassium increase when kidney failure, calcium decreased when ascites.

Keyword: Alcoholic liver disease, electrolytes disorder, mineral metabolism disorder.

\section{I. ĐĂTT VẤN ĐỀ}

Bệnh gan do rượu là bệnh rất thường gặp ở các nước châu Á, nghiện rượu nặng trong thời gian dài làm tế bào gan bị nhiễm mỡ, các dải xớ hình thành dần dần dẫn đến bệnh xơ gan do rượu[1]. Ở bệnh nhân xơ gan do tình trạng suy chức năng gan làm cho bệnh nhân thấy mệt mỏi, giảm vị giác, khứu giác, buồn nôn và nôn làm cho sự hấp thu thức ăn giảm sút. Thêm nữa tình trạng tiêu hóa kém, hấp thu kém do giảm bài tiết dịch tụy, giảm acid mật; vi khuẩn phát triển quá mức do giảm nhu động ruột, mất protein thứ phát do tăng áp lực tĩnh mạch cửa, tình trạng kháng insulin và tổng hợp sút kém protein dẫn đến giảm khối lượng cớ, giảm cân nặng, thiếu hụt dinh dưỡng trong cơ thể[2].

Cơ thể bình thường sẽ duy trì nồng độ chất khoáng và điện giải bình thường trong máu, trong môi trường nội bào và thành phần tối ưu trong cấu trúc xương. Rượu sẽ làm biến đổi cấu trúc tế bào gan từ đó cũng làm thay đổi chức năng thông thường của gan đồng thời ảnh hưởng đến hoạt động của các cơ quan khác như ruột, thận và xương ngoài ra còn ảnh hưởng đến hoạt động của hormone tuyến giáp và sự tổng hợp vitamin $D$. Từ đó dẫn đến rối loạn chuyển hóa các chất khoáng và điện giải. Sự rối loạn này đã được đề cập đến nhưng nguyên nhân gây ra đến nay vẫn còn là một hiểu biết hạn chế và người ta cho rằng có liên quan đến sự tiến triển của bệnh xơ gan[3],[4]. Chúng tôi tiến hành nghiên cứu này với mục tiêu là:

- Mô tả ti lệ rối loạn điện giải, khoáng chất ở bệnh nhân xơ gan.

- Đánh giá mối liên quan giữa rối loạn điện giải, khoáng chất với một số yêu tố.

\section{II. ĐỐI TƯỢNG VÀ PHƯƠNG PHÁP NGHIÊN CỨU \\ 2.1.Đối tượng nghiên cứu}

- Tiêu chuẩn chọn đối tượng nghiên cứu:

+ Bệnh nhân được chẩn đoán xơ gan do rượu theo hướng dẫn của American College of Gastroenterology Faculty gồm: hội chứng tăng áp cửa và hội chứng suy tế bào gan; uống rượu trên $\geq 30 \mathrm{~g} /$ ngày thời gian trên 5 năm[1], [5].

- Tiêu chuẩn loại trừ: bệnh nhân có bệnh khác gây rối loạn điện giải và khoáng chất.

2.2.Thời gian, địa điểm nghiên cứu

- Thời gian nghiên cứu: Từ tháng 11 năm 2019 đến tháng 4 năm 2020.

- Địa điểm nghiên cứu: Bệnh viện Trung ương quân đội 108, Hà Nội.

\subsection{Phương pháp nghiên cứu}

- Nghiên cứu mô tả.

- Thiết kế tiến cứu.

2.4.Cỡ mấu và cách chọn mẫu

* Công thức cỡ mẫu: sử dụng công thức tính cõ̃ mẫu ước tính 1 tỉ lệ của quần thể:

$$
\mathrm{n}=Z_{(1-\alpha / 2)}^{2} \frac{p q}{d^{2}}
$$


Trong đó: $Z_{(1-a / 2)}$ : hệ số giới hạn tin cậy, chọn mức tin cậy $95 \% \rightarrow Z_{(1-a / 2)}=1$,96. d: độ chính xác mong muốn, chọn $\mathrm{d}=0,1 \cdot \mathrm{p}=0,15$ (theo nghiên cứu của Mann R.E, $15 \%$ số bệnh nhân nghiện rượu phát triển thành xơ gan[6]). Áp dụng công thức tính được $n=49$ bệnh nhân. Chúng tôi chọn ngẫu nhiên được 66 bệnh nhân đủ tiêu chuẩn vào nghiên cứu.

\subsection{Các bước tiến hành nghiên cứu}

2.5.1. Khám lâm sàng: Tất cả các bệnh nhân được hỏi tiền sử, bệnh sử, khám lâm sàng các triệu chứng của bệnh xơ gan.

\subsubsection{Xét nghiệm cận lâm sàng:}

- Các bệnh nhân được lấy $2 \mathrm{ml}$ máu tĩnh mạch vào mỗi ônng nghiệm có chất chống đông để xét nghiệm công thức máu và đông máu bằng máy Cell Dyn 3700 (Abbot) tại khoa Huyết học. Lây $2,5 \mathrm{ml}$ máu tînh mạch vào một ống nghiệm không có chất chống đông làm xét nghiệm sinh hóa bằng máy Olympus Au 640 tại khoa Sinh hóa.

\subsection{Chỉ tiêu nghiên cứu}

* Giới: nam, nữ.

* Phân loại giai đoạn xơ gan theo Child Pugh 1991.

* Chỉ tiêu cận lâm sàng:

+ Natri máu bình thường: 135-145 mmol/l.

+ Kali máu bình thường: 3,5-5 mmol/l.

+ Clo máu bình thường: 98-106 mmol/l.

+ Calci TP máu bình thường: 2,2-2,6 mmol/l.

+ Magie máu bình thường: 0,73-1,06 mmol/l.

+ Phospho máu bình thường: $0,8-1,5 \mathrm{mmol} / \mathrm{l}$.

$+\mathrm{NH} 3$ máu bình thường $<55 \mu \mathrm{mol} / \mathrm{l}$.

+ Đánh giá bệnh lí gan mất bù theo bảng điểm Child Pugh 1991.

2.7. Xử lý số liệu. Số liệu được xử lý bằng phần mềm thống kề y học SPSS 22.0. Phân tích các số liệu bằng thuật toán thống kê mô tả tần số các biến Frequencies, Descriptive. So sánh giá trị trung bình nhiêu nhóm bằng phân tích independent samples T test, one-way ANOVA, có ý nghĩa thống kê khi $p<0,05$.

\section{KẾT QUẢ NGHIÊN CỨU}

\section{Bảng 1: Đặc điểm chung của đôi tượng} nghiên cứu

\begin{tabular}{|c|c|c|c|}
\hline \multicolumn{2}{|c|}{ Đă̆c điếm } & $\mathbf{n ( 6 6 )}$ & $\mathbf{\%}$ \\
\hline \multicolumn{3}{|c|}{ Tuối trung bình } & \multicolumn{2}{c|}{$55.98 \pm 11.25$} \\
\hline \multirow{2}{*}{ Giới } & Nam & 65 & 98.5 \\
\cline { 2 - 4 } & Nữ & 1 & 1.5 \\
\hline \multirow{2}{*}{ Child } & $\mathrm{A}$ & 6 & 9.1 \\
\cline { 2 - 4 } Pugh & $\mathrm{B}$ & 30 & 45.5 \\
\cline { 2 - 4 } & $\mathrm{C}$ & 30 & 45.5 \\
\hline \multicolumn{3}{|c|}{ Child Pugh score (5-15) } & \multicolumn{2}{|c|}{$9.64 \pm 2.4$} \\
\hline
\end{tabular}

Nhân xét: Tuối trung bình của nhóm nghiên cứu là $55.98 \pm 11.25$. Nam giới chiếm tỉ lệ cao $98.5 \%$. Child Pugh $B, C$ chiếm tỉ lệ cao với cùng $45.5 \%$. Điểm Child dao động từ 5 đến 15 , trung bình là $9.64 \pm 2.4$.

Bảng 2: Đặc điểm các chỉ số xét nghiêm

\begin{tabular}{|c|c|}
\hline Chỉ số & Trung bình, độ lệch chuấn \\
\hline WBC & $8.2 \pm 5.2$ \\
\hline RBC & $3.5 \pm 0.8$ \\
\hline PLT & $151.4 \pm 115.9$ \\
\hline Ure & $7.2 \pm 5.3$ \\
\hline Creatinin & $97.1 \pm 68.3$ \\
\hline AST & $144.7 \pm 228.7$ \\
\hline ALT & $67.7 \pm 171.9$ \\
\hline GGT & $338.7 \pm 446.6$ \\
\hline
\end{tabular}

Nhận xét: Các chỉ số huyết học không thay đổi nhiều. Men AST trung bình là $144.7 \pm 228.7$ tăng cao hơn so với men ALT trung bình là 67.7 \pm 171.9. Men GGT tăng rất cao với giá trị trung bình là $338.7 \pm 446.6$.

Bảng 3: Rôí loạn về điện giải đồ

\begin{tabular}{|c|c|c|c|c|}
\hline \multicolumn{2}{|c|}{ Chỉ số } & $\mathbf{n}$ & $\%$ & Trung bình, độ lệch chuấn \\
\hline $\begin{array}{c}\mathrm{Na}(\mathrm{mmol} / \mathrm{L}) \\
\mathrm{Min} \max (118-141)\end{array}$ & $\begin{array}{c}\text { Giảm } \\
\text { Binh thương }\end{array}$ & $\frac{41}{25}$ & $\frac{62.1}{379}$ & $132.6 \pm 5.2$ \\
\hline & Giảm & 20 & 30.3 & \\
\hline $\begin{array}{c}K(\mathrm{mmol} / \mathrm{L}) \\
\operatorname{Min} \max (18-5.8)\end{array}$ & Bình thường & 40 & 60.6 & $3.8 \pm 0.8$ \\
\hline & Tăng & 6 & 9.1 & \\
\hline $\mathrm{Cl}(\mathrm{mmol} / \mathrm{L})$ & Giảm & 26 & 39.4 & \\
\hline Min $\max (75-114)$ & Bình thường & 29 & 43.9 & $98.4 \pm 7.9$ \\
\hline MIII, Max (12-114) & Tăng & 11 & 16.7 & \\
\hline CaTP $(\mathrm{mmol} / \mathrm{L})$ & Giảm & 50 & 75.8 & $2.05 \pm 0.19$ \\
\hline Min, $\max (1.34-2.54)$ & Bình thương & 16 & 24.2 & \\
\hline
\end{tabular}

Nhận xét: Ca TP giảm chiếm tỉ lệ cao nhất với $75.8 \%$, thứ hai là $\mathrm{Na}$ giảm với tỉ lệ $62.1 \%$. Cl giảm với tỉ lệ 39.4\%, tăng trong $16.7 \%$ các trường hợp. K giảm với tỉ lệ $30.3 \%$, tăng với tỉ lệ $16.7 \%$. Giá trị trung bình của cả $\mathrm{Na}, \mathrm{K}, \mathrm{Cl}$ và $\mathrm{Ca}$ TP đều giảm.

Bảng 4: Rôí loạn về Magie, Phospho

\begin{tabular}{|c|c|c|c|c|}
\hline \multicolumn{2}{|c|}{ Chi số } & n & \% & Trung bình, độ lệch chuấn \\
\hline $\mathrm{Mg}$ & Giảm & 45 & 68.2 & $0.68 \pm 0.13$ \\
\hline
\end{tabular}




\begin{tabular}{|c|c|c|c|c|}
\hline Min, max (0.33-1.09) & Binh thường & 20 & 30.3 & \\
\cline { 2 - 4 } & Tăng & 1 & 1.5 & \\
\hline \multirow{2}{*}{ Pho } & Giảm & 15 & 22.7 & \multirow{2}{*}{$0.99 \pm 0.28$} \\
\cline { 2 - 4 } Min $(0.40-2.01)$ & Bình thường & 48 & 72.7 & \multirow{2}{*}{0.9} \\
\cline { 2 - 4 } & Tăng & 3 & 4.5 & \\
\hline
\end{tabular}

Nhận xét: Pho giảm chiếm tỉ lệ cao $22.7 \%$, chỉ tăng trong $4.5 \%$ các trường hợp. Giá trị trung bình của Pho trong máu là $0.99 \pm 0.28$ không giảm so với bình thường.

Bảng 5: So sánh nồng độ trung bình các chất theo Child Pugh

\begin{tabular}{|c|c|c|c|c|}
\hline Các chất & Child A (6) & Child B (30) & Child C (30) & P \\
\hline $\mathrm{Na}$ & $132.5 \pm 8.1$ & $133.1 \pm 5.9$ & $131.9 \pm 3.8$ & 0.6 \\
\hline $\mathrm{K}$ & $4.4 \pm 0.8$ & $4.1 \pm 0.8$ & $3.4 \pm 0.7$ & 0.002 \\
\hline $\mathrm{Cl}$ & $92.0 \pm 11.1$ & $99.4 \pm 7.9$ & $98.7 \pm 6.7$ & 0.1 \\
\hline $\mathrm{CaTP}$ & $2.2 \pm 0.1$ & $2.1 \pm 0.2$ & $1.9 \pm 0.1$ & 0.01 \\
\hline $\mathrm{Mg}$ & $0.65 \pm 0.14$ & $0.70 \pm 0.17$ & $0.66 \pm 0.13$ & 0.5 \\
\hline $\mathrm{Pho}$ & $0.92 \pm 0.29$ & $1.05 \pm 0.26$ & $0.93 \pm 0.29$ & 0.2 \\
\hline
\end{tabular}

Nhận xét: So sánh trung bình các chất thì $\mathrm{K}$ và CaTP giảm dần theo mức độ xơ gan, nồng độ $\mathrm{K}$ ở mức Child $C$ là thấp nhất $3.4 \pm 0.7$, nồng độ CaTP ở mức Child $C$ là thấp nhất $1.9 \pm 0.1$, những sự khác biệt này có ý nghĩa $p<0,05$. Các chất khác không có sự khác biệt theo mức độ xơ gan.

Bảng 6: So sánh nồng độ trung bình các chất theo tình trạng suy thận

\begin{tabular}{|c|c|c|c|}
\hline Các chất & Không suy thận (50) & Có suy thận (16) & P \\
\hline $\mathrm{Na}$ & $132.7 \pm 5.1$ & $131.9 \pm 5.5$ & 0.5 \\
\hline $\mathrm{K}$ & $3.6 \pm 0.7$ & $4.2 \pm 1.1$ & 0.02 \\
\hline $\mathrm{Cl}$ & $97.9 \pm 7.8$ & $99.8 \pm 7.9$ & 0.4 \\
\hline $\mathrm{CaTP}$ & $2.03 \pm 0.19$ & $2.07 \pm 0.21$ & 0.5 \\
\hline $\mathrm{Mg}$ & $0.68 \pm 0.14$ & $0.67 \pm 0.11$ & 0.3 \\
\hline $\mathrm{Pho}$ & $0.97 \pm 0.25$ & $1.04 \pm 0.35$ & 0.3 \\
\hline
\end{tabular}

Nhận xét: So sánh trung bình các chất thì $K$ tăng lên khi có suy thận, nồng độ $K$ khi có suy thận là $4.2 \pm 1.1$, nồng độ $\mathrm{K}$ khi không suy thận là $3.6 \pm 0.7$, sự khác biệt này có ý nghĩa $p<0,05$. Các chất khác không có sự khác biệt theo tình trạng suy thận.

Bảng 7: So sánh nồng độ̣ trung bình các chât theo tình trạng cổ trướng

\begin{tabular}{|c|c|c|c|}
\hline Các chất & Không cố trướng(20) & Cố trướng nhiêu (46) & P \\
\hline $\mathrm{Na}$ & $133.6 \pm 5.5$ & $132.1 \pm 5.1$ & 0.2 \\
\hline $\mathrm{K}$ & $3.8 \pm 0.9$ & $3.7 \pm 0.8$ & 0.7 \\
\hline $\mathrm{Cl}$ & $96.2 \pm 11.2$ & $99.4 \pm 5.8$ & 0.1 \\
\hline $\mathrm{CaTP}$ & $2.13 \pm 0.20$ & $2.01 \pm 0.18$ & 0.01 \\
\hline $\mathrm{Mg}$ & $0.68 \pm 0.10$ & $0.69 \pm 0.14$ & 0.8 \\
\hline $\mathrm{Pho}$ & $0.92 \pm 0.21$ & $1.02 \pm 0.30$ & 0.2 \\
\hline
\end{tabular}

Nhận xét: So sánh trung bình các chất thì CaTP giảm khi có cố trướng, nồng độ CaTP khi có cổ trướng là $2.01 \pm 0.15$. Nồng độ $\mathrm{Mg}$ khi không cổ trướng cũng giảm thấp $0.65 \pm 0.17$, sự khác biệt này có ý nghĩa $p<0,05$. Các chất khác không có sự khác biệt khi có cổ trướng.

\section{BÀN LUẬN}

Bệnh gan do rượu thường gặp ở nam hơn là ở nữ đặc biệt ở các quốc gia đang phát triển do thói quen uống rượu thường xuyên trong sinh hoạt hàng ngày. Bệnh viện Trung ương quân đội 108 là cơ sở y tế tuyến cuối nên các bệnh nhân xơ gan chuyển từ tuyến dưới lên đa phần là bệnh ở giai đoạn cuối, chức năng gan đã suy giảm nhiêu, vì thế tỉ lệ bệnh nhân Child $C$ trong nghiên cứu này là khá cao, điểm Child trung bình xấp xỉ cận dưới của giai đoạn xơ gan nặng. Ở giai đoạn gan nhiễm mõ do rượu chất béo sẽ tích lũy trong tế bào gan, gây phản ứng viêm tối thiểu và gan chưa bị xơ. Bệnh nhân thường có biểu hiện tăng men gan nhẹ, bao gồm gammaglutamyl transpeptidase, aspartate aminotransferase và alanine aminotransferase[6]. Khi bệnh nhân bị xơ hóa gan nặng thì chúng tôi thấy ngoài các biểu hiện suy giảm chức năng gan men GGT vẫn là chỉ số tăng lên đáng kể nhất.

Xơ gan là dạng bệnh gan rượu nghiêm trọng nhất và dẫn đển tử vong khi có các biến chứng nặng. Lúc này mô sẹo thay thế mô gan bình thường, làm gián đoạn lưu lượng máu qua gan và ngăn không cho nó hoạt động bình thường. Sự tích tụ bất thường của chất béo trong các tế bà̀ gan càng làm ảnh hưởng xấu đến chức năng chuyển hóa của gan. Tình trạng tăng áp lực tĩnh 
mach cửa cũng góp phần làm sự rối loan này trầm trọng thêm. Rối loạn điện giải và khoáng chất thường xảy ra ở bệnh nhân mắc bệnh gan giai đoạn cuối; các cơ chế bệnh sinh thường phức tạp, đấy là một thách thức trong chẩn đoán và điều trị cho bác sĩ. Thông thường, những rối loạn này không phát triển ở những bệnh nhân xơ gan còn bù, nhưng với sự xuất hiện của các biến chứng kinh điển của bệnh xớ gan như cổ trướng, suy thận, viêm phúc mạc do vi khuẩn tự phát và chảy máu do giãn tĩnh mạch, nhiều chất điện giải và khoáng chất bi rối loạn. Giảm natri máu ở bệnh nhân xơ gan rất hay gặp, chúng tôi thấy có $62.1 \%$ số bệnh nhân có tình trạng giảm natri máu. Giảm natri có thể do giảm thể tích hoăc do tăng thể tích. Trong nghiên cứu này tî lể suy thận là 16/66, nên nguyên nhân gây giảm natri rất có thể do giảm thể tích, hậu quả của mất dịch qua thận vì sử dụng thuốc lợi tiểu quá mức, bệnh nhân bị mất nước, suy thận trước thận. Giảm natri cũng có thể do tăng thể tích do suy yếu khả năng bài xuất nước tự do qua thận gây tình trạng ứ nước, thể tích dịch ngoại bào tăng và hạ natri máu do pha loãng vì tỉ lệ cổ trướng chúng tôi thấy ở 46/66 bệnh nhân. Giảm natri máu làm cho tình trạng suy chức năng gan nặng hơn, tăng tỉ lệ biến chứng và tử vong.

Nếu giảm natri máu nặng sẽ xuất hiện hội chứng gan thận. Suy thận mạn tính với việc giảm mức lọc câu thận xuống $<30 \%$ so với bình thường có thể làm giảm sản xuất $1,25-(\mathrm{OH}) 2$ vitamin D. Khi có suy thận mạn, tăng phospho máu và cường cận giáp thứ phát sẽ xảy ra. Canxi huyết thanh có xu hướng trong phạm vi bình thường thấp. Hạ canxi máu thường không được quan sát thấy trong sự hiện diện của hàm lượng vitamin D $25(\mathrm{OH})$ thấp do sự gia tăng của PTH, sẽ huy động canxi từ xương[7]. Xơ gan rượu không phải là nguyên nhân chính làm giảm vitamin D $25(\mathrm{OH})$ vì hơn $90 \%$ tế bào gan bị rối loạn chức năng trước khi vitamin D $25(\mathrm{OH})$ giảm xuống mức dưới bình thường. Tuy nhiên, kém hấp thu chất béo đường ruột xảy ra ở bệnh xơ gan và ứ mật có thể là nguyển nhân gây ra thiếu vitamin $\mathrm{D}[7]$. Tình trạng giảm canxi máu ở bệnh nhân xơ gan rượu còn do suy tuyến cận giáp thoáng qua do thiếu magie[8]. Chúng tôi thấy rằng có $68.2 \%$ số bệnh nhân giảm magie máu. Chuyển hóa magie và canxi có liên quan chặt chẽ. Sự hấp thu ở ruột và bài tiết qua thận của hai ion phụ thuộc lẫn nhau. Các nguyên nhân thường gặp nhất của hạ magie ở bệnh xơ gan là giảm lượng ăn vào, suy giảm hấp thu đường ruột và mất qua thận.
Hơn nữa, hạ magie máu nặng gây ra suy tuyến cận giáp chức năng. Các nghiên cứu in vitro đã chứng minh rằng magie có thể điều chỉnh sự tiết hormone tuyến cận giáp theo cách tương tự như canxi. Giảm nồng độ magie cấp tính kích thích bài tiết PTH và tăng nồng độ cấp tính làm giảm bài tiết. Magie có khả năng đóng một vai trò quan trọng trong chuyển hóa vitamin D. Một số bệnh nhân bị hạ canxi máu và thiếu magie kháng với liều vitamin $D$ dược lý hoặc có thể có dạng còi xương kháng vitamin $D$ phụ thuộc magie. Sự suy giảm phospho đã được quan sát thấy đi kèm với sự gia tăng magiê và canxi trong nước tiểu. Giảm phospho là tình trạng ít gặp khi chỉ chiếm tỉ lệ 22.7\%.

Khi phân tích mối liên quan giữa nồng độ các chất với một số yếu tố như mức độ xơ gan, tình trạng suy thận, tình trạng cổ trướng thì thấy rằng canxi máu là chất có sự suy giảm có ý nghĩa nhất khi xơ gan tiến triển nặng. Kali máu cũng giảm dần theo mức độ xơ gan, $\mathrm{p}<0,05$, nhưng khi bệnh nhân xơ gan bị suy thận thì nồng độ kali máu lại tăng lên. Nồng độ magie máu thì giảm ngay cả khi xơ gan ở giai đoạn Child A không có cổ trướng, với bênh nhân có cố trướng thậm chí nồng độ trung bình của magie còn cao hởn.

\section{KẾT LUÂN}

Sau nghiên cứu chúng tôi có một số kết luận như sau: Tỉ lệ giảm natri máu là $62.1 \%$

Kali máu giảm chiếm tỉ lệ $30.3 \%$, tăng $9.1 \%$.

Clo máu giảm chiếm tỉ lệ $39.4 \%$, tăng $16.7 \%$.

Canxi máu giảm chiếm tỉ lệ $75.8 \%$.

Magie máu giảm chiếm tỉ lệ $68.2 \%$, tăng $1.5 \%$.

Phospho máu giảm chiếm tỉ lệ $22.7 \%$, tăng $4.5 \%$.

Kali máu và canxi máu giảm theo mức độ nặng của xơ gan, $p<0,05$.

Kali máu tăng khi có suy thận và canxi máu giảm khi có cổ trướng, $\mathrm{p}<0,05$.

\section{TÀI LIÊU THAM KHẢO}

1. Singal A.K, Bataller R, Ahn J, et al. (2018). ACG Clinical Guideline: Alcoholic Liver Disease. Am J Gastroenterol., 113(2): 175-194.

2. Rossi R.E., Conte D, Massironi S. (2015). Diagnosis and treatment of nutritional deficiencies in alcoholic liver disease: Overview of available evidence and open issues. Science Direct, 47(10): 819-825.

3. George J. (2006). Mineral metabolism in dimethylnitrosamine-induced hepatic fibrosis. Clinical Biochemistry, 39(2006): 984-991.

4. George J, Ganesh H.K, Acharya $S$, et al. (2009). Bone mineral density and disorders of mineral metabolism in chronic liver disease. World J Gastroenterol., 15(28): 3516-3522. 
5. Jaurigue M.M, Cappell M.S. (2014). Therapy for alcoholic liver disease. World J Gastroenterol. 20(9): 2143-58.

6. Mann R.E, Smart R.G, Govoni R. (2003). The Epidemiology of Alcoholic Liver Disease. Alcohol Research \& Health., 27(3): 209-219.
7. Schafer A.L, Shoback D.M. (2016). Hypocalcemia: Diagnosis and Treatment. South Dartmouth (MA): MDText.com, Inc. 2000-

8. Chiba T, Okimura Y, Inatome T, et al. (1987). Hypocalcemic crisis in alcoholic fatty liver: transient hypoparathyroidism due to magnesium deficiency. Am J Gastroenterol., 82(10):1084-7.

\section{BƯớC ĐÂU ĐÁNH GIÁ KẾT QUẢ CỦA KỸ THUÂTT CẮT U THẦN KINH NộI TIẾT ĐƯờ'NG TIÊU HOÁ QUA NộI SOI ỐNG MỀM}

\section{TÓM TẮT}

Nghiên cứu thu thập 25 bệnh nhân với 26 khối u có chẩn đoán u thần kinh nội tiết đường tiêu hóa qua kết quả mô bệnh học từ 01/01/2016 đến 31/07/2020. Chủ yếu các khối ở trưc tràng $(84,6 \%)$, xuất phát tai lớp dưới niêm mạc $(61,1 \%)$ và có kích thước dưới $2 \mathrm{~cm}$ $(100 \%)$. Tất cả các khối u có ranh giới rõ và xung quanh không thấy có hạch. Các bệnh nhân được cắt khối u bằng snare có tiêm phồng adrenalin 1/10000 $(73,1 \%)$ hoắc theo phương pháp cắt polyp không tiêm adrenalin $(26,9 \%)$. Tỷ lê căt hết toàn bô các khối u đạt $100 \%$. Mức độ thực hiện kỹ thuật đạt kết quả tốt là 24 bênh nhân $(96,0 \%)$, có 1 bênh nhân không đạt $(4,0 \%)$ do sau căt xảy ra tai biển thủng trực tràng phải phẫu thuật nội soi qua ống hậu môn để khâu đóng. Tất cả các khối u đều có kết quả mô bệnh học của NET điển hình và có $8 / 25$ bênh nhân có kết quả hóa mô miến dịch đối với một số maker CD56, Chromogranin, CK10, HE, Ki67, Neuron-specific enolase, synaptiphysin. Nghiên cứu bước đầu cho thấy kỹ thuật cắt u qua nội soi ống mềm là kỹ thuật có hiệu quả và an toàn trong điều trị u thần kinh nội tiết đường tiêu hoá.

Từ khoá: u thần kinh nội tiết, carcinoid, cắt u qua nội soi, cắt hớt niêm mạc qua nội soi

\section{SUMMARY}

PRELIMINARY RESULT OF

\section{NEUROENDOCRINE TUMOUR RESECTION} USING FLEXIBLE ENDOSCOPY

From January 1, 2016 to July 31, 2020, our study collected 25 patients which had 26 tumors with a histological diagnosis of gastrointestinal neuroendocrine tumors (NET). Most tumors located in the rectum $(84.6 \%)$, originated from the submucosa

\footnotetext{
${ }^{1}$ Viện Nghiên cứu và đào tạo Tiêu hóa, gan mật,

2Trường Đai hoc Y Hà Nôi

${ }^{3}$ Bệnh viện Đại học Y Hà Nội,

${ }^{4}$ Trường Đại học Y Dược, Đại học Quốc gia Hà Nội

Chiu trách nhiệm chính: Đào Việt Hằng

Email: hangdao.fsh@gmail.com

Ngày nhận bài: 16.11.2020

Ngày phản biện khoa học: 29.12.2020

Ngày duyệt bài: 7.01.2021
}

\section{Đào Việt Hằng 1,2,3, Trần Ngọc Minh², Trần Thị Thu Trang ${ }^{1,4}$, Đào Văn Long ${ }^{1,2}$}

$(61.1 \%)$ and were less than $2 \mathrm{~cm}(100 \%)$. All tumors had clear delineation and had no lymph nodes. The tumors were removed by snare resection assisted by submucosal injections of $1 / 10000$ adrenaline $(73.1 \%)$ or by non-assisted snare resection $(26.9 \%)$. The rate of complete removal was $100 \%$. 24 patients $(96.0 \%)$ achieved good results, 1 patient $(4.0 \%)$ had rectal perforation after the intervention and had to undergo laparoscopic surgery for closure. On histopathology, all tumors had typical characteristics of NET. On immunohistochemistry, $8 / 25$ patients showed expressions of several CD56 makers, Chromogranin, CK10, HE, Ki67, Neuron-specific enolase, synaptophysin. Our preliminary study showed that endoscopic resection was effective and safe in the treatment of neuroendocrine tumors

Keywords: Neuroendocrine tumors, NET, carcinoid, endoscopic resection, endoscopic mucosal resection, EMR

\section{I. Đă̆T VẤN ĐỀ}

U thần kinh nội tiết (neuroendocrine tumors NETs) là khối u có nguồn gốc từ các tế bào thần kinh nội tiết, hiếm gặp và có đặc điểm lâm sàng đa dạng, không điển hình. Tỷ lệ mắc trên thế giới được ghi nhận tăng dần trong những năm gần đây dao động từ 1,09/100000 (năm 1973), $5,25 / 100000$ (năm 2004) và 6,98/100000 (năm 2012) [1]. NET có thể xuất hiện ở nhiều cơ quan trên cơ thể như đường tiêu hoá, buồng trứng, phổi, tinh hoàn, thanh quản... Trong đó, đường tiêu hoá, cụ thể là ruột non và trực tràng là vị trí thường gặp nhất. Các khối u này có thể được phát hiện tình cờ trong quá trình nội soi sàng lọc hoặc khi người bệnh có một số triệu chứng như chảy máu, tiêu chảy.

Theo khuyến cáo của một số Hiệp hội ung thư trên thế giới, nguyên tắc quản lý chung đối với NET là xác định vị trí, giai đoạn, đặc điểm mô bênh học, độ biệt hoá, từ đó cân nhắc lựa chọn điêu trị phương pháp tại chỗ (cắt qua nội soi, phẫu thuật, nút mạch, đốt sóng cao tân) hoặc sứ dụng các liệu pháp toàn thân (hoá trị liệu, miễn 